\title{
EXTRACTIVISM IN THE GLOBAL MARKET AND HUMAN RIGHTS: THE TRAGEDY OF THE MUDSLIDE IN MARIANA (2015)
}

\author{
Myriam Bahia Lopes ${ }^{1}$ \\ Bruno de Oliveira Biazatti²
}

\section{Introduction}

As we read the Portuguese narrative that celebrates Portugal's early mundialization in the $16^{\text {th }}$ century, we find that, since the first Portuguese man put their step in Brazilian soil, the History of Brazil has been associated with mining activities. For instance, the Letter of Pêro Vaz de Caminha to the King of Portugal, the first written document about its newly colonial lands, expressly mentions the existence of gold and silver to be mined in Brazil. ${ }^{3}$

One current mining pole of the Southeast Region of Brazil is the River Doce Basin, which extends itself over part of the territory of two Brazilian states: Minas Gerais, where the source of the river can be found, and Espírito Santo, where the river reaches the Atlantic Ocean. In the Minas Gerais's part of this basin lies the Iron Quadrangle

\footnotetext{
${ }^{1}$ Myriam Bahia Lopes is a Professor of the School of Architecture of the Federal University of Minas Gerais, in Brazil. She is a Researcher and Advisor of the UFMG Department of Critical and Historical Analysis of Architecture and Urbanism. She also coordinates the Center for the History of Science and Technology (NEHCIT). She has a doctoral degree by the Université Paris-Diderot and was a CAPES Senior Researcher before the École des Hautes Études en Sciences Sociales (2009 and 2015).

${ }^{2}$ Bruno de Oliveira Biazatti is Bachelor of Laws from the Federal University of Minas Gerais, in Brazil. He coordinated the Research Group on International Law, the Research Group on International Humanitarian Law and the Research Group on International Courts and Tribunals. He is a researcher of the International Law Center (CEDIN).
}

\begin{abstract}
${ }^{3}$ See the following part of the Letter of Pêro Vaz de Caminha: "When [the natives] came, the Captain was seating in a chair, well dressed, wearing a golden very great necklace, and, under his feet, there was carpet above a dais. Sancho de Tovar, Simon de Miranda, Nicolau Coelho, Aires Correia, and the rest of us was sitting on the floor, by the carpet. They lit up torches. They entered. But they did no sign of courtesy, neither spoken to the Captain or anyone. However, one of them looked at the Captain's necklace, and began waving his hand to the ground and then to the necklace, as if he was telling us that there was gold there. He also looked at a silver candlestick and once again waved to the land and back to the candlestick as if there was also silver." This is the original version in Portuguese: "O Capitão, quando [os índios] vieram, estava sentado em uma cadeira, bem vestido, com um colar de ouro mui grande ao pescoço, e aos pés uma alcatifa por estrado. Sancho de Tovar, Simão de Miranda, Nicolau Coelho, Aires Correia, e nós outros que aqui na nau com ele vamos, sentados no chão, pela alcatifa. Acenderam-se tochas. Entraram. Mas não fizeram sinal de cortesia, nem de falar ao Capitão nem a ninguém. Porém um deles pôs olho no colar do Capitão, e começou de acenar com a mão para a terra e depois para o colar, como que nos dizendo que ali havia ouro. Também olhou para um castiçal de prata e assim mesmo acenava para a terra e novamente para o castiçal como se lá também houvesse prata."
\end{abstract}

RRASILIANA- Journal for Brazilian Studies. Vol. 5, n.2 (July 2017). ISSN 2245-4373. 
("Quadrilátero Ferrifero" in Portuguese), an area of about 7,000 square kilometers from which $73 \%$ of the whole national iron production comes from ${ }^{4}$. Hence, the Iron Quadrangle is the true core of Brazilian mining activities. Since colonial times, the region has been a crucial economic asset. The extraction of gold, silver and precious stones by Portuguese explorers began in the late $17^{\text {th }}$ century and reached its apogee in the $18^{\text {th }}$ century ${ }^{5}$.

In order to provide a natural barrier to all these precious resources, the downstream part of the River Doce was left unexplored for many centuries ${ }^{6}$. The Portuguese Crown was afraid that it would be an easy door to pirates from the ocean to reach the highlands, the region of exploitation. The port of Victoria at the state of Espírito Santo remained a closed door till the $20^{\text {th }}$ century and only after the railway connection between the Iron Quadrangle and this port was established, it became an important way out for Brazilian minerals ${ }^{7}$. In 2012, 52\% of all iron ore extracted in Brazilian soil left the country in ships departing from the port of Victoria. ${ }^{8}$

After the Second World War, and specially in the period of Civil-Military Dictatorship (1964-1985), the Brazilian system of exporting commodities (mainly iron ore) included an intense commerce with Asian countries, in particular Japan. This new design of the global trade of minerals was possible by the intensification of the production and transport of commodities in an unprecedented huge scale ${ }^{9}$. In 2015, once again, mining companies invested in an unattended intensification of the production to maintain their profits, despite the reduction of the price of iron ore in the international market ${ }^{10}$. The

\footnotetext{
${ }^{4}$ Departamento de Pesquisas e Estudos Econômicos."Minério de Ferro", Bradesco Bank, 2016, p.20.

${ }^{5}$ João Daniel Lima de Almeida. História do Brasil, Brasília: FUNAG, 2013, p.44-52.

${ }^{6}$ Haruf Salmen Espindola, "Vale do Rio Doce: Fronteira, industrialização e colapso socioambiental", Fronteiras: Journal of Social, Technological and Environmental Science,v.4, n.1, 2015, p. 160-206, p.166; José Teixeira de Oliveira, História do Estado do Espírito Santo, 3rd ed.,Vitória, Arquivo Público do Estado do Espírito Santo, Secretaria de Estado da Cultura, 2008, p.185-186.

${ }^{7}$ José Teixeira de Oliveira, História do Estado do Espírito Santo, 3rd ed., Vitória, Arquivo Público do Estado do Espírito Santo, Secretaria de Estado da Cultura, 2008, p.468.

${ }^{8}$ Departamento de Pesquisas e Estudos Econômicos."Minério de Ferro", Bradesco Bank, 2016, p.21.

${ }^{9}$ Olintho Pereira da Silva, "A mineração em Minas Gerais: passado, presente e futuro", Geonomos, vol.3, no.1, 1995, p.82-83.
}

10 SAMARCO. Parecer de Licenciamento ambiental. Disponível em: <http://giaia.eco.br/wpcontent/uploads/2015/11/PARECER-UNICO-N\%C2\%BA-262-2013.-PROTOCOLO-1782789-2013_Samarco.pdf>. Acesso em: 12 de maio de 2016. 
acceleration of the iron ore extraction was achieved ignoring the official reports on the fact that the tailing dams of the region was dangerously reaching their maximum capacity ${ }^{11}$. Furthermore, several of those dams were built in a higher position than cities and communities, representing a permanent threat to local populations.

One of these compromised waste reservoirs was the Fundão Dam, located in the city of Mariana (Minas Gerais) and owed by Samarco Mining, a Brazilian mining company founded in 1977 and currently controlled by Vale and the EnglishAustralian BHP Billiton ${ }^{12}$. On November 5, 2015, around 4:20pm, the Fundão Dam collapsed and released 34 million cubic meters of mud into the valley of the Gualaxo do Norte Stream, whose waters flows into the River Doce ${ }^{13}$.

Forty-five minutes after the breakdown of the Fundão Dam, the huge wave of mud reached the Santarém Dam, which did not resist the flow and also broke, adding over 1.5 million cubic meters of mud into the valley ${ }^{14}$. The wave of toxic residues continued to move down, reaching the District of Bento Rodrigues, where 600 people live. This district was completely destroyed by the mud. In the next 16 days, the mud flowed

\footnotetext{
${ }^{11}$ In 2013, Minas Gerais Prosecution Office requested a technical report to the Prístino Institute, a research institute specialized on conditions of conservation and rational use of natural resources, concerning the safety conditions of the Fundão Dam, belonging to Samarco. The report attested that there was an imminent risk of collapse (Prístino Institute, "Laudo Técnico em resposta ao Parecer Único N N 257/2013: Análise Técnica Referente à Revalidação da Licença Operacional da Barragem de Rejeitos do Fundão - Samarco Mineração S/A", Belo Horizonte, 21 October 2013. Available at: <http://crimideia.com.br/miniver/wp-content/uploads/2015/11/Laudo-barragem-daSamarco-em-2013.pdf $>$ ). Although the content of the report was quite clear, no safety measure was effectively taken by Samarco. Accordingly, less than two years after, the Fundão Dam indeed broken. After the disaster, the main Brazilian newspapers indicated the existence of the report and the negligence of Samarco: Pedro Rocha Franco, "Laudo técnico alertou para instabilidade em área de barragem em Mariana", Estado de Minas, 6 November 2015. Available at: <http:/www.em.com.br/app/noticia/gerais/2015/11/06/interna_gerais,705089/laudo-tecnico-alertoupara-instabilidade-em-area-de-barragem-em-marian.shtml >; Bruno Ribeiro et al., "Estudo de 2013 alertava para risco de barragem romper", Estado de São Paulo, 7 November 2015. Available at: $<$ http://brasil.estadao.com.br/noticias/geral,estudo-de-2013-alertava-para-risco-de-barragem-romper,10000001364>; Marcelo Leite and Estevão Bertoni, "'Barragem que se rompeu não voltará a funcionar', diz presidente da Samarco", Folha de São Paulo, 26 December 2015. Available at: <ttp://www1.folha.uol.com.br/cotidiano/2015/12/1723149barragem-que-se-rompeu-nao-voltara-a-funcionar-diz-chefe-da-samarco.shtml $>$.
}

${ }^{12}$ Bruno Milanez et al. "Antes fosse mais leve a carga: avaliação dos aspectos econômicos, políticos e sociais do desastre da Samarco/Vale/BHP em Mariana (MG)", Final Report of PoEMAS, Federal University of Juiz de Fora, December 2015, p.18.

${ }^{13}$ Minas Gerais State Environmental Foundation - FEAM, "Inventory of dams in the State of Minas Gerais", Doc. no. FEAM-DGER-GERIM-RT-03/2015, 2016, p.46-50; Brazil. "Plano de Trabalho da Comissão para avaliar a Política Nacional de Segurança de Barragens e o Sistema Nacional de Informações sobre Segurança de Barragens", Senate Congress, 1 December 2015, p.2; Brazilian Water National Agency. "Encarte Especial sobre a Bacia do Rio Doce Rompimento da Barragem em Mariana/MG", Superintendência de Planejamento de Recursos Hídricos, Brasília, 2016, pp.23-25.

${ }^{14}$ Ibid.

RRASILIANA- Journal for Brazilian Studies. Vol. 5, n.2 (July 2017). ISSN 2245-4373. 
through the River Doce and reached the Atlantic Ocean ${ }^{15}$. In its path, the mud also impacted indigenous communities, such as the Krenak People, a group also known as Botocudos. For indigenous culture, specially the indians of the river (borum do uatu), the death of the river (called Uatu) carries several material and spiritual impacts ${ }^{16}$. Accordingly, the collapse of the Fundão Dam is the largest environmental disaster in Brazilian history ${ }^{17}$, with unprecedented impacts on flora, fauna and human life ${ }^{18}$.

This paper aims to present some remarks about the implications of the Fundão Dam disaster to the protection of human rights in Brazil and to the Brazilian legislation on dam safety. We will focus on three different aspects: the obligation to avoid human rights violations, the right to information and the right to water.

\section{The positive obligation to prevent human rights violations}

It is a well-established principle of International Human Rights Law that States have the positive obligation to take preventive measures in order to avoid human rights violations under their jurisdiction. ${ }^{19}$ Hence, a proper notion of protection of human rights does not only cover compensation for violations of those rights, but also entails an obligation for

\footnotetext{
${ }^{15}$ Ibid.

${ }^{16}$ KRENAK, Itamar Souza Ferreira et al. Água, leito das vidas Krenak, Uatu Hoom, Cipó Voador, 2009; PARAÍSO, Maria Hilda. "Os Botocudos e sua Trajetória Histórica”, p.420-421. In: CUNHA, Manuela Carneiro da (ed.). História dos Índios no Brasil. São Paulo: Fapesp/SMC/CIA das Letras, 1992.

${ }^{17}$ Brazil. "Preliminary Report of the External Commission on the Dam Breach in the Region of Mariana - MG", Chamber of the Representatives - Congress, CD158408782307, December 2015, p.11; Brazil. "Plano de Trabalho da Comissão para avaliar a Política Nacional de Segurança de Barragens e o Sistema Nacional de Informações sobre Segurança de Barragens", Senate - Congress, 1 December 2015, p.3.

${ }^{18}$ Geraldo Wilson Fernandes et al. "Deep into the mud: ecological and socio-economic impacts of the dam breach in Mariana, Brazil”, Natureza e Conservação, vol.14, 2016, p.35-45; Herton Escobar. "Mud tsunami wreaks ecological havoc in Brazil", Science, vol. 350, issue 6265, 2015, pp.1138-1139.

${ }^{19}$ UNHRC, General Comment No.6: The right to life (art. 6), CCPROR, UNDoc.HRI/GEN/1/Rev.1, 1994, para.5; Lantsov v. Russia, Comm. No. 763/1997, UNHRC, Mar. 26, 2002, para.9(2); Chongwe v. Zambia, Comm. No. 821/1998, UNHRC, Oct. 25, 2000, para.5(2); Osman v. United Kingdom, Application No. 23452/94, ECtHR, Judgment of 28 October 1998, paras.115-116; Anguelova v. Bulgaria, Application No. 38361/97, ECtHR, Judgment of 13 June 2002, paras.123-131; Case of the Street Children (Villagran-Morales et al. v Guatemala) (Merits) IACtHR, Judgment of November 19, 1999, para.144; Case of the Ituango Massacres (Merits) IACtHR, Judgment of July 1, 2006, paras. 130 and 131 .
}

RRASILIANA- Journal for Brazilian Studies. Vol. 5, n.2 (July 2017). ISSN 2245-4373. 
States to prevent their occurrence ${ }^{20}$. In the case Velasquez Rodriguez $v$. Honduras, the InterAmerican Court of Human Rights upheld this obligation in the following terms:

This duty to prevent [breaches of human rights obligations] includes all those means of a legal, political, administrative and cultural nature that promote the protection of human rights and ensure that any violations are considered and treated as illegal acts, which, as such may lead to the punishment of those responsible and the obligation to indemnify the victims for damages. It is not possible to make a detailed list of all such measures, since they vary with the law and the conditions of each State Party. ${ }^{21}$

In the context of disasters, this obligation creates the burden on States to take all feasible measures aimed at preventing and mitigating their harmful effects ${ }^{22}$. The application of the duty to prevent human rights violations in the context of natural and man-made disasters was expressly recognized by the European Court of Human Rights. Generally speaking, this Court ruled that the negligence to adopt preventive measures that would have avoided or mitigated the consequences of disasters constitutes a violation of the right to life. The two main decisions on this matter is the case Öneryildiz v. Turkey (2004) and the case Budayeva and others v. Russia (2008). The former deals with a methane explosion in a public refuse dump in Istanbul. The waste erupted by the explosion engulfed ten slum dwellings nearby, killing 39 people. Two years before the incident, Turkish authorities had access to a report pointing out the need to prevent a likely explosion of the methane from the decomposing material ${ }^{23}$. Since no measure was taken to prevent the accident, the European Court of Human Rights concluded that Turkey violated the human right to life of the victims ${ }^{24}$. In its judgment, the Court argued that

[...] [the right to life] does not solely concern deaths resulting from the use of force by an agent of the State but also [...] lays down a

\footnotetext{
${ }^{20} \mathrm{UN}$ International Law Commission. Sixth report on the protection of persons in the event of disasters, Special Rapporteur Eduardo Valencia-Ospina, UNDoc.A/CN.4/662, 3 May 2013, para.42.

${ }^{21}$ Velasquez Rodriguez v. Honduras (Merits) IACtHR, Judgment of 29 July 1988, Series C, No. 4, paras.174-175.

${ }^{22} \mathrm{UN}$ International Law Commission. Sixth report on the protection of persons in the event of disasters, Special Rapporteur Eduardo Valencia-Ospina, UNDoc.A/CN.4/662, 3 May 2013, para.46.

${ }^{23}$ Öneryildiz v. Turkey, Application No. 48939/99, ECtHR, Judgment of 30 November 2004, paras.10-18.

${ }^{24}$ Ibid., paras.89-110.
}

3RASILIANA- Journal for Brazilian Studies. Vol. 5, n.2 (July 2017). ISSN 2245-4373. 
positive obligation on States to take appropriate steps to safeguard the lives of those within their jurisdiction. [...] This positive obligation entails above all a primary duty on the State to put in place a legislative and administrative framework designed to provide effective deterrence against threats to the right to life. ${ }^{25}$

On the other hand, the case Budayeva and others $v$. Russia refers to a natural mudslide that destroyed the mountainous city of Tyrnauz, in Russia, and killed several people. Although Tyrnauz had retention dams installed to protect the population from mudslides, they were in terrible conditions. Weeks before the incident, Russian authorities had received a number of warnings about the increasing risk of large-scale mudslides and the weakness of the retention dams. The Mountain Institute, an agency responsible for monitoring weather hazards in Russian mountainous areas, even recommended the establishment of observation points in strategic locations of the mountain and also the issuing of an emergency warnings to evacuate the population. However, none of the suggested measures were taken ${ }^{26}$. Accordingly, the European Court of Human Rights ruled that the Russia's failure to avoid the destructive consequences of the mudslide amounts to a violation of the human right to life ${ }^{27}$. While clarifying the precise scope of the obligation to take positive-preventive measures, the Court stated that

[i]n the sphere of emergency relief, where the State is directly involved in the protection of human lives through the mitigation of natural hazards, these considerations should apply in so far as the circumstances of a particular case point to the imminence of a natural hazard that had been clearly identifiable, and especially where it concerned a recurring calamity affecting a distinct area developed for human habitation or use [...] The scope of the positive obligations imputable to the State in the particular

\footnotetext{
${ }^{25}$ Ibid., paras. 128-129.

${ }^{26}$ Budayeva v. Russia, Applications No. 15339/02, 21166/02, 20058/02, 11673/02 and 15343/02, ECtHR, Judgment of 20 March 2008, paras.13-38.

${ }^{27}$ Ibid., paras. 128-137 and 146-160.
}

RRASILIANA- Journal for Brazilian Studies. Vol. 5, n.2 (July 2017). ISSN 2245-4373. 
circumstances would depend on the origin of the threat and the extent to which one or the other risk is susceptible to mitigation. ${ }^{28}$

Under those two precedents, States may commit a wrongful act under the human right to life when they neglect their obligation to take preventive measures when a disaster is identifiable, foreseeable and avoidable. ${ }^{29}$ In addition, States have to adopt effective domestic legislation in order to avoid risks to the population, especially risks from disasters. ${ }^{30}$

In Brazil, the main legal instrument concerning tailing dams is the Dam Safety National Policy Act (Federal Law 12,334/2010), adopted in November 10, 2010 by the Brazilian Congress. A great contribution of this statute is the creation of the National System of Dam Safety Information which provides a "digital record of dam safety conditions throughout the entire national territory [of Brazil]". ${ }^{31}$ The Federal Law $12,334 / 2010$ also ensures a classification system to describe and classify the risks of the dams nationwide. The risk classification has three categories (low, medium and high) and each tailing dam should be supervised and classified by the NMPD ${ }^{32}$.

However, the Federal Law 12,334/2010 has several technical gaps that open the door to human rights violations. A very serious one concerns the Emergency Action Plan (EAP), which is generally not mandatory. That statute determines that the NMPD must order the adoption of an EAP only when the concerned dam is classified with a high Associated Potential Damage $\mathrm{e}^{33}$.

Furthermore, the Federal Law 12,334/2010 only demands the existence of the Plan. There is no procedure to compel the mining company to follow its own plan. This was the case of Samarco. In 2009, it hired the company Rescue Training International to develop an emergency plan to protect its staff and communities in the event of a dam

\footnotetext{
${ }^{28}$ Ibid., para. 137.

${ }^{29}$ UN International Law Commission. Sixth report on the protection of persons in the event of disasters, Special Rapporteur Eduardo Valencia-Ospina, UNDoc.A/CN.4/662, 3 May 2013, para.53.

${ }^{30}$ Öneryildiz v. Turkey, Application No. 48939/99, ECtHR, Judgment of 30 November 2004, para.129.

${ }^{31}$ Brazil. "Dam Safety National Policy Act - Law no. 12,334/2010", 10 November 2010, art.13.

${ }^{32}$ Ibid., art. 7.

${ }^{33}$ Brazil. "Dam Safety National Policy Act - Law 12,334/2010", 10 November 2010, art.11.
} 
rupture in Mariana. Instead of implementing this plan, Samarco hired another company to write a new plan, much less comprehensive than the previous one. Minas Gerais state authorities had pointed out several failures in the second plan: it lacked an evacuation plan during an emergency; there was no population training to react to a possible dam collapse; residents of Bento Rodrigues were notified by phone only after the dam had broken and many phone numbers in the plan were outdated; there was no sirens in the area; and the plan wrongly predicted that the mud from the Fundão Dam would never reach the River Doce in the case of a breach ${ }^{34}$. In the indictment of six Samarco employees for environmental crimes related to the Fundão disaster, the Brazilian Federal Police expressly mentioned the inefficiency of Samarco's EAP ${ }^{35}$.

The commission established by the Brazilian Senate after the Fundão disaster to improve the National Policy of Dam Safety admitted that the Federal Law no. $12,334 / 2010$, in its current terms, is inefficient and needs urgent reforms, especially in the system of periodic dam monitoring and risk classification ${ }^{36}$. According to the commission, that statute does not specify the periodicity of the risk evaluation of the dams and does not determine the minimal professional requirements of the risk evaluators. It also does not detail the content of the Dam Safety Plan, a plan that every mining company with dams must have to avoid accidents, even when a dam is classified with high risk ${ }^{37}$.

Accordingly, although Brazil has its own Dam Safety National Policy (Federal Law no. 12,334/2010), such legal framework lacks efficiency and has a lot of gaps, leaving open doors to mining companies to act as they wish. The most notorious piece of evidence of this ineffectiveness is the Fundão disaster itself, which happened under the watch of Brazilian authorities. Thus, the Federal Law no. 12,334/2010 must be improved in order to become a real and effective legal framework able to avoid human rights

\footnotetext{
${ }^{34}$ Gustavo Werneck. "Plano de emergência para barragens da Samarco era ineficaz, acusa Polícia Federal", Estado de Minas, $\quad 31 \quad$ January $2016 . \quad$ Available at: $<$ http://www.em.com.br/app/noticia/gerais/2015/11/24/interna_gerais, 710870/samarco-contratou-plano-deemergencia-para-desastre-mas-nunca-pos-em.shtml $>$.

${ }^{35}$ Daniel Camargos. "Plano de emergência para barragens da Samarco era ineficaz, acusa Polícia Federal", Estado de Minas, $31 \quad$ January $2016 . \quad$ Available at: $<$ http://www.em.com.br/app/noticia/gerais/2016/01/31/interna_gerais,730015/plano-de-emergencia-para-barragensda-samarco-era-ineficaz-acusa-pf.shtml>.

${ }^{36}$ Brazil. "Plano de Trabalho da Comissão para avaliar a Política Nacional de Segurança de Barragens e o Sistema Nacional de Informações sobre Segurança de Barragens", Senate - Congress, 1 December 2015, p.9-10.

${ }^{37}$ Ibid.
} 
violations related to tailing dam disasters. Without those modifications, Brazil is not fulfilling its obligation to adopt effective measures to avoid risks to the human life.

\section{The human right to information}

The Law no. 12,334/2010 also has to follow the right to information, because "[...] information is crucial to preventing human rights violations resulting from exposure to hazardous substances and wastes" 38 . Hence, Brazilian authorities and mining companies must be able to provide, in few hours, reliable information about the risks of the mud released from dam collapses. Referring to the Fundão disaster, Başkut Tuncak, the UN Special Rapporteur on human rights and hazardous substances and wastes, said that "[i]t is not acceptable that it has taken three weeks for information about the toxic risks of the mining disaster to surface." ${ }^{39}$ In a report drafted by Mr. Tuncak and adopted by the UN Human Rights Council on 8 July 2015, it was confirmed that every human being has the right to receive information, which "[...] encompasses the right of individuals to request and receive information of public interest and information concerning themselves that may affect their individual rights" 40 . Knowing that hazardous substances and wastes can cause illness, including cancer, heart and lung disease, mental disabilities and diabetes, it is clear that individuals have a legal interest in requesting quick access to information on these substances, especially when they are exposed to them ${ }^{41}$.

In addition, information is a precondition for the realization of a series of human rights, such as the right to safe drinking water and sanitation, the right to the highest attainable standard of physical and mental health, the right to food and the right to a healthy environment ${ }^{42}$. The lack of information on hazardous substances also can amount

\footnotetext{
${ }^{38}$ UN Human Rights Council. "Report of the Special Rapporteur on the implications for human rights of the environmentally sound management and disposal of hazardous substances and wastes, Başkut Tuncak", UNDoc.A/HRC/30/40, 8 July 2015, para.3.

${ }^{39}$ Office of the United Nations High Commissioner for Human Rights, "Brazilian mine disaster: 'This is not the time for defensive posturing' - UN rights experts", Press Release, Geneva, 25 November 2015. Available at: $<$ http://www.ohchr.org/en/NewsEvents/Pages/DisplayNews.aspx?NewsID=16803\&LangID=E $>$

${ }^{40}$ UN Human Rights Council. "Report of the Special Rapporteur on the implications for human rights of the environmentally sound management and disposal of hazardous substances and wastes, Başkut Tuncak", UNDoc.A/HRC/30/40, 8 July 2015, para.22.

${ }^{41}$ Ibid., paras.2-3.

${ }^{42}$ Ibid., para. 23 .
} 
to breaches of the right to life, because uninformed people could drink, eat or breath toxic substances, exposing themselves, unborn babies and babies who breastfeed to risk ${ }^{43}$.

Moreover, according to the Article 7 of the International Covenant on Civil and Political Rights, "[...] no one shall be subjected without his free consent to medical or scientific experimentation"44, which comprises exposure to substances with unknown potential adverse effects ${ }^{45}$. Hence, all States, including Brazil, must ensure that individuals under their jurisdiction are informed about hazardous substances, because lack of information, in connection with a lack of consent to be exposed to those materials and their risks, can give rise to a breach of Article $7^{46}$.

Reports by victims of the accident and by residents of the region, which include professors and students of the Federal University of Ouro Preto (UFOP), especially the reports in the local journal "The Siren" (A Sirene), created for publicizing the effects of the tragedy, indicate that in addition to not gaining access to information, the evictees received false statements. One of this untruthful information was that the local population was not in danger because their homes were located below the dam. The title of the journal ("The Siren") aims to keep in mind the fact that Samarco did not have a siren to warn the population in case of an accident ${ }^{47}$.

\section{The human right to water}

Water sustains life. ${ }^{48}$ Although this is an uncontested truth, 884 million people do not have access to safe drinking water worldwide and approximately 1.5 million children under 5 years old die each year as a result of water and sanitation related diseases ${ }^{49}$. Also,

${ }^{43}$ Ibid., para. 25 .

${ }^{44}$ International Covenant on Civil and Political Rights, 1966, 999 UNTS 171, art.7.

${ }^{45}$ Ibid., para. 27.

${ }^{46}$ Ibid.

${ }^{47}$ The website of the journal "The Siren” follows: $<\underline{\text { https://issuu.com/jornalasirene }>.}$

${ }^{48}$ The Dublin Statement on Water and Sustainable Development, International Conference on Water and the Environment, Dublin, Ireland, 31 January 1992, Principle no. 1.

${ }^{49}$ The human right to water and sanitation, UNGA Resolution 64/292, UNDoc.A/RES/64/292, 3 August 2010, Preamble.

RRASILIANA- Journal for Brazilian Studies. Vol. 5, n.2 (July 2017). ISSN 2245-4373. 
lack of access to water kills more children annually than AIDS, malaria and measles all combined ${ }^{50}$. Given this alarming scenario, the International Human Rights Law provides to every human being the fundamental right to water, which "[...] entitles everyone to sufficient, safe, acceptable, physically accessible and affordable water for personal and domestic uses." 51

The right to water was acknowledged by the UN General Assembly in two separate resolutions. The first one is the Resolution no. 54/175 on the right of development, which was adopted on 17 December 1999. This resolution states: "The rights to food and clean water are fundamental human rights and their promotion constitutes a moral imperative both for national Governments and for the international community." 52 The other one is the Resolution no. 64/292, adopted on 28 July 2010, which "[r]ecognizes the right to safe and clean drinking water and sanitation as a human right [...]."53

The right to water is essential to the achievement of several other human rights ${ }^{54}$. One example is the right to life, which "encompasses existence in human dignity with the minimum necessities of life $\mathrm{e}^{\prime 55}$ and the right to not be deprived of the necessary means for livelihood. ${ }^{56}$ In this perspective, the supply of drinking water is mandatory in order to guarantee the realization of the minimal conditions of life with dignity, ${ }^{57}$ since water is

\footnotetext{
${ }^{50}$ UN General Assembly "General Assembly Adopts Resolution Recognizing Access to Clean Water, Sanitation as Human Right, by Recorded Vote of 122 in Favour, None against, 41 Abstentions", Press Conference no. GA/10967, 28 July 2010. Available at: <http://www.un.org/press/en/2010/ga10967.doc.htm>.

${ }^{51}$ Committee on Economic, Social and Cultural Rights, General Comment No. 15: The Right to Water (Arts. 11 and 12 of the Covenant), 29th Session of the Committee on Economic, Social and Cultural Rights, Doc.E/C.12/2002/11, 20 January 2003, para.2.

52 The right to development, UNGA Resolution 54/175, UNDoc.A/RES/54/175, 15 February 2000, art.12(a).

${ }^{53}$ The human right to water and sanitation, UNGA Resolution 64/292, UNDoc.A/RES/64/292, 3 August 2010 , para.1.

54 Ibid.

${ }^{55}$ UN Commission on Human Rights, Human Rights and Extreme Poverty, Human Rights Res. 2005/16, para.1(b).

${ }^{56}$ International Covenant on Civil and Political Rights, 16 December 1966, 999 UNTS 171,art.1(2); F. Menghistu, "The Satisfaction of Survival Requirements", p.63. In Bertrand G. Ramcharan (ed.). The Right to Life in International Law, Leiden: Martinus Nijhoff, 1985.

57 Stephen C. McCafrrey. "A Human Right to Water: Domestic and International Implication", Georgetown Environmental Law Review, vol.5, 1992, p.10; Peter H. Gleick, "The Human Right to Water", Pacific Institute, 2007, p.2; John Scanlon, Angela Cassar \& Noémi Nemes. "Water as an Human Right?", Environmental Law and Policy Paper No. 51, International Union for Conservation of Nature, 2004, p.4.
} 
one of the key elements "[...] to prevent death from dehydration, to reduce the risk of water-related disease and to provide for consumption, cooking, personal and domestic hygienic requirements". 58

The access to safe water is also condition for the realization of economic, social and cultural rights. In its general comment on the right to water, the UN Committee on Economic, Social and Cultural Rights stated the following relevant remarks:

Water is required for a range of different purposes, besides personal and domestic uses, to realize many of the [rights contained in the International Covenant on Economic, Social and Cultural Rights]. For instance, water is necessary to produce food (right to adequate food) and ensure environmental hygiene (right to health). Water is essential for securing livelihoods (right to gain a living by work) and enjoying certain cultural practices (right to take part in cultural life). Nevertheless, priority in the allocation of water must be given to the right to water for personal and domestic uses. Priority should also be given to the water resources required to prevent starvation and disease, as well as water required to meet the core obligations of each of the Covenant rights..$^{59}$

Article 1(2) of the International Covenant on Economic, Social and Cultural Rights, which establishes the right to the necessary means of subsistence, ${ }^{60}$ also comprises the right to water for irrigating crops and animal watering ${ }^{61}$. Article 12(2)(b) imposes the obligation to ensure individuals a hygienic and safe environment, which includes the duty to take measures in order to prevent human exposure to toxic water. ${ }^{62}$

\footnotetext{
${ }^{58}$ Committee on Economic, Social and Cultural Rights, General Comment No. 15: The Right to Water (Arts. 11 and 12 of the Covenant), 29th Session of the Committee on Economic, Social and Cultural Rights, Doc.E/C.12/2002/11, 20 January 2003, para.2.

${ }^{59}$ Ibid., para.6.

${ }^{60}$ International Covenant on Economic, Social and Cultural Rights, (1966), 993 U.N.T.S., art.1(2).

${ }^{61}$ Committee on Economic, Social and Cultural Rights, General Comment No. 15: The Right to Water (Arts. 11 and 12 of the Covenant), 29th Session of the Committee on Economic, Social and Cultural Rights, Doc.E/C.12/2002/11, 20 January 2003, para. 7.

${ }^{62}$ Ibid., para.8; Committee on Economic, Social and Cultural Rights, General Comment 14: The right to the highest attainable standard of health, 22nd Session of the Committee on Economic, Social and Cultural Rights, U.N.Doc.E/C.12/2000/4, 2000, para.15.
}

RRASILIANA- Journal for Brazilian Studies. Vol. 5, n.2 (July 2017). ISSN 2245-4373. 
The right to water is also provided for in three UN human rights treaties relating to the rights of people with special needs. The first one is the Convention on the Elimination of All Forms of Discrimination against Women, adopted on 18 December 1979. This treaty imposes to the States Parties the obligation to take all appropriate measures to ensure to women in rural areas "[...] adequate living conditions, particularly in relation to housing, sanitation, electricity and water supply, transport and communications." ${ }^{63}$ [emphasis added]

The second treaty is the Convention on the Rights of the Child, which was adopted on 20 November 1989. Its Article 24(2)(c) determines that States Parties shall pursue full implementation of the right of the child to the enjoyment of the highest attainable standard of health and, for that, shall take appropriate measures:

[t]o combat disease and malnutrition, including within the framework of primary health care, through, inter alia, the application of readily available technology and through the provision of adequate nutritious foods and clean drinking-water, taking into consideration the dangers and risks of environmental pollution..$^{64}$ [emphasis added]

Lastly, we have the Convention on the Rights of Persons with Disabilities, adopted on 13 December 2006. While enshrining the right to adequate standard of living and social protection, Article 28(2)(a) determines that States Parties

[...] shall take appropriate steps [...] [t]o ensure equal access by persons with disabilities to clean water services, and to ensure access to appropriate and affordable services, devices and other assistance for disability-related needs. ${ }^{65}$ [emphasis added]

Alongside the international legal framework on human rights, it is worth noting that several States expressly recognize, in their domestic legislation, the human right to safe water, such as Tunisia, ${ }^{66}$ Kenya, ${ }^{67}$ South Africa, ${ }^{68}$ Democratic Republic of Congo, ${ }^{69}$

\footnotetext{
${ }^{63}$ Convention on the Elimination of All Forms of Discrimination against Women, 1249 UNTS 1, 1 March 1980 , art.14(2)(h).

${ }^{64}$ Convention on the Rights of the Child, 1577 UNTS 3, New York, 20 November 1989, art.24(2)(c).

${ }^{65}$ Convention on the Rights of Persons with Disabilities, 2515 UNTS 3, New York, 13 December 2006, art.28(2)(a).

${ }^{66}$ Tunisia. Constitution de la République Tunisienne, 26 January 2014, art.44. This provision states the following: "Le droit à l'eau est garanti. La préservation de l'eau et son utilisation rationnelle sont un devoir pour l'Etat et la société".
}

RRASILIANA- Journal for Brazilian Studies. Vol. 5, n.2 (July 2017). ISSN 2245-4373. 


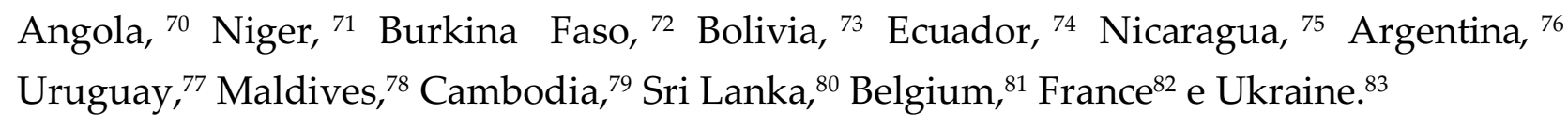

${ }^{67}$ Kenya. Constitution of Kenya, 28 August 2010, art.43(1)(d). This provision states the following: "Every person has the right: $[\ldots]$ to clean and safe water in adequate quantities".

${ }^{68}$ South Africa. Constitution of the Republic of South Africa, as last amended by Amendment Act No. 3 of 20031996, 10 December 1996, art.27. This provision states the following: "Everyone has the right to have access to: (...) (b) sufficient food and water;".

${ }^{69}$ Democratic Republic of the Congo. Constitution of the Democratic Republic of the Congo, 18 February 2006, art.48. This provision states the following: "The right to decent housing, the right of access to drinking water and to electric energy are guaranteed. The law establishes the conditions for the exercise of these rights."

${ }^{70}$ Angola. Lei n. 6/02, 21 June 2002, art.9(1). This provision states the following: "A gestão das águas obedece aos seguintes princípios: (a) do direito do cidadão e entidades colectivas à água".

${ }^{71}$ Niger. La Constitution de la VIIème République, 18 February 2010, art.12. This provision states the following: "Chacun a droit à la vie, à la santé, à l'intégrité physique et morale, à une alimentation saine et suffisante, à l'eau potable, à l'éducation et à l'instruction dans les conditions définies par la loi."

72 Burkina Faso. Loi No. 002-2001/AN Portant Loi d'Orientation Relative a la Gestion de l'Eau, 8 February 2001, art.1. This provision states the following: "La loi reconnaît le droit de chacun à disposer de l'eau correspondant à ses besoins et aux exigences élémentaires de sa vie et de sa dignité."

${ }^{73}$ Bolivia. Nueva Constitución Política del Estado de Bolivia, 21 October 2008, art.373(I). This provision states the following: "El agua constituye un derecho fundamentalísimo para la vida, en el marco de la soberanía del pueblo. El Estado promoverá el uso y acceso al agua sobre la base de principios de solidaridad, complementariedad, reciprocidad, equidad, diversidad y sustentabilidad."

${ }^{74}$ Ecuador. Constitution of the Republic of Ecuador, 20 October 2008, art.12. This provision states the following: "The human right to water is essential and cannot be waived. Water constitutes a national strategic asset for the use by the public and it is inalienable, not subject to a statute of limitations, immune from seizure and essential for life."

${ }^{75}$ Nicaragua. Nicaragua's Constitution of 1987 with Amendments through 2005, 1 January 1987, art.105. This provision states the following: "It is the obligation of the State to promote, facilitate, and regulate the provision of basic public services of energy, communications, water, transportation, road infrastructure, ports, and airports to the people, and access to these is their inalienable right."

${ }^{76}$ Argentina. Ley $n^{\circ} 3.295$ Ley de Gestión Ambiental del Agua de la Ciudad Autónoma de Buenos Aires, 26 November 2009, art.3. This provision states the following: "La ciudad garantiza a todos sus habitantes el acceso al agua potable en cantidad y calidad suficientes para usos personales y doméstico como derecho humano fundamental."

${ }^{77}$ Uruguay . Constitución de la República Oriental del Uruguay, 15 February 1967, art.47. This provision states the following: "[...] El agua es un recurso natural esencial para la vida. El acceso al agua potable y el acceso al saneamiento, constituyen derechos humanos fundamentales."

${ }^{78}$ Maldives. Constitution of the Republic of the Maldives, 7 August 2008, art.23. This provision states the following: "Every citizen the following rights pursuant to this Constitution, and the State undertakes to achieve the progressive realization of these rights by reasonable measures within its ability and resources: (a) adequate and nutritious food and clean water".

${ }^{79}$ Cambodia. Law on Water Resources Management of the Kingdom of Cambodia, 29 June 2007, art.11. This provision states the following: "Every person has the right to use water resources for his/her vital human need including

RRASILIANA- Journal for Brazilian Studies. Vol. 5, n.2 (July 2017). ISSN 2245-4373. 
Moreover, one could not forget that approximately $65 \%$ of the human body is composed of water. Thus, the destruction of the sources of drinking water can truly prevent the perpetuation of human life in the affected areas. The degradation of the environmental conditions necessary to sustain life, especially access to clean water, could even give rise to genocide. The international prohibition to genocide aims to guarantee the physical existence of national, ethnical, racial or religious groups. ${ }^{84}$

The UN Convention on the Prevention and Punishment of the Crime of Genocide, adopted on 9 December 1948, indicates that a genocide can be performed by "[d]eliberately inflicting on the group conditions of life calculated to bring about its physical destruction in whole or in part"85. It is clear that environmental degradation could fulfil this threshold and constitute genocide. William A. Schabas explains that "[t]hreats to the integrity of the environment can conceivably imperil the survival of a group or people. If associated with the intent to destroy the group, the definition of genocide may apply." 86 The UN Sub-Commission on Prevention of Discrimination and

drinking, washing, bathing and other domestic purposes including watering for animal husbandry, fishing and the irrigation of domestic gardens and orchards, in a manner that will not affect other legal right of others."

${ }^{80}$ Sri Lanka. National Policy on Drinking Water, 2007, topic 1.1. This provision states the following: "Safe water, suitable for human consumption is a scarce and a limited resource which is under threat of pollution, contamination and waste. This ever-dwindling resource is indispensable for sustenance of life on the planet and in particular the well being of humans. Safe drinking water is considered a key factor contributing towards overall economic and social development of a country. Accordingly, access to safe drinking water is considered as an inalienable right of the people. The Government has assigned the top most priority for the provision of safe drinking water in achieving sustainable economic and social development."

${ }^{81}$ Belgium. Decret relatif au cycle de l'eau et instituant une Societe publique de gestion de l'eau, 15 April 1999 , art.1. This provision states the following : "L'eau fait partie du patrimoine commun de la Région. Le cycle de l'eau est géré de façon globale et intégrée, dans le constant souci d'en assurer la pérennité dans le cadre d'un développement durable. Toute personne a le droit de disposer d'une eau potable de qualité et en quantité suffisante pour son alimentation, ses besoins domestiques et sa santé."

${ }^{82}$ France. Code de l'environnement, 2000, art. L.210-1. This provision states the following: "Dans le cadre des lois et règlements ainsi que des droits antérieurement établis, l'usage de l'eau appartient à tous et chaque personne physique, pour son alimentation et son hygiène, a le droit d'accéder à l'eau potable dans des conditions économiquement acceptables par tous."

${ }^{83}$ Ukraine. The Law of Ukraine On Ensuring Sanitary and Epidemic Safety of the Population, 7 February 2002, art.4. This provision states the following: "Citizens shall have the following rights to: foodstuffs, drinking water, work conditions, education, up-bringing, household surroundings, recreation, and the environment that are safe for their life and health."

84 Yoram Dinstein, "Collective Human Rights of Peoples and Minorities", International \& Comparative Law Quarterly, Vol. 25, Issue 1, Jan de 1976, p102-120, p.105.

${ }^{85}$ Convention on the Prevention and Punishment of the Crime of Genocide, 78 UNTS 277, 9 December 1948, art.2(c).

RRASILIANA- Journal for Brazilian Studies. Vol. 5, n.2 (July 2017). ISSN 2245-4373. 
Protection of Minorities ${ }^{87}$ even used the term "ecocide" to describe "[...] adverse alterations, often irreparable, to the environment [...] which threaten the existence of entire populations, whether deliberately or with criminal negligence" 88 .

In general, mining activities create a significant demand for water, which can compromise the reserves for human consumption. Mining companies need substantial quantities of water for processing and transport of minerals, control of dust, cleaning of equipment and also consumption by their own employees ${ }^{89}$. In times of dry, industries often store water in reservoirs and, in times of rain, they discharge contaminated surplus water into local rivers. Both practices have serious consequences on the access to drinking water by local populations. Also, dam failures can pollute waterways and landscape alterations can negatively impact organism lifecycles, biodiversity and water cycles $^{90}$.

Accordingly, Brazil should change its legislation on dam safety in order to ensure clean water in case of catastrophes. There is no provision in the Federal Law 12,334/2010 binding public authorities and private companies to provide water to fulfill the basic needs of the affected population, such as cooking and hygiene. Every mining company must have its own plan to ensure drinking water to the population and this plan must be drafted in clear, feasible, comprehensive and objective terms. This plan also shall establish technical procedures to quickly verify the quality and level of toxins found in the water compromised by the waste released from the breached dam.

\footnotetext{
${ }^{86}$ William A. Schabas. Genocide in International Law: The Crime of Crimes, 2 ed., Cambridge, Cambridge University Press, 2009, p.235.

${ }^{87}$ In 1999, the Sub-Commission on Prevention of Discrimination and Protection of Minorities was renamed to "SubCommission on the Promotion and Protection of Human Rights".

${ }^{88}$ UN Sub-Commission on Prevention of Discrimination and Protection of Minorities, Revised and updated report on the question of the prevention and punishment of the crime of genocide prepared by $\mathrm{Mr}$. B . Whitake, UNDoc.E/CN.4/Sub.2/1985/6, 2 July 1985, p.17.

${ }^{89}$ Deanna Kem et al. "Mining, water and human rights: making the connection", Journal of Cleaner Production, vol.18, 1553-1562, 2010, p.1554.

${ }^{90}$ Ibid.
}

RRASILIANA- Journal for Brazilian Studies. Vol. 5, n.2 (July 2017). ISSN 2245-4373. 


\section{Final remarks}

The criminal scale of the production of transnational companies that concentrate capital and power exceeds the government and society's capability of negotiation and decision. This concentration paves the way for the mining companies to ignore many obligations of the local, national and international legislation. The excessive scale and rate of production represent a grave interference in the modus vivendi of local populations, making impossible to develop life with dignity and safety.

Moreover, the lack of compliance by mining companies can provoke catastrophes not only in the local level, but also in the national and international levels. For instance, the collapse of the Fundão Dam was able to affect 39 cities in two different states of Brazil (Minas Gerais and Espírito Santo). As the toxic mud advanced for 420 kilometers in the River Doce Basin, until it had reached the ocean, 1.2 million people were affected by its harmful effects. In addition, the mud has spread itself into the sea, reaching the cost of other Brazilian states ${ }^{91}$.

Also, there is the vile possibility to privatize the responsibility for such terrible environmental crimes by insurance. Under those circumstances, the risk of human deaths and irreparable damage to the environment is reduced to a financial calculus of compensation. The true value of the human life and the environment is lost in the middle of a fight for monetary gain between the mining corporations, insurance companies and public authorities. Accordingly, the only way to control mining companies is to have strong laws and effective institutions to enforce them. Also, the material content of these laws must follow international human rights standards, in order to successfully protect the human person from risks and damages.

Finally, the breach of the Fundão Dam and its ongoing effects reveal the limits of the environmental laws, of the monitoring system aimed at the activities of transnational mining companies and of the judicial branch. Permissiveness between the federal, state and municipal governments, the judiciary and private companies can be observed in the funding by these companies of electoral campaigns of the largest Brazilian political parties, debt relieves, and also by the fact that the foundation created to manage the funds for compensation for the damages associated with the Fundão Dam disaster is controlled by Samarco itself. The realization of equal rights in a democratic environment

\footnotetext{
${ }^{91}$ These data can be found here: Movimento dos Atingidos por Barragens, "Infográfico da tragédia: Os números da maior tragédia ambiental brasileira", $2016 . \quad$ Available at: $<$ http://tragedianunciada.mabnacional.org.br/2015/12/15/infografico-da-tragedia/>.
} 
do not actually occur in the case studied in the present paper. The study in light of human rights allows us to rethink the values of our society, by bringing them closer to the concept of life, especially the rights to water, information and prevention from violations of the law.

\section{References}

Angola. Lei n. 6/02, 21 June 2002.

Anguelova v. Bulgaria, Application No. 38361/97, ECtHR, Judgment of 13 June 2002.

Argentina. Ley n 3.295 Ley de Gestión Ambiental del Agua de la Ciudad Autónoma de Buenos Aires, 26 November 2009.

Belgium. Decret relatif au cycle de l'eau et instituant une Societe publique de gestion de l'eau, 15 April 1999.

Bolivia. Nueva Constitución Política del Estado de Bolivia, 21 October 2008.

Brazil. "Dam Safety National Policy Act - Law no. 12,334/2010", 10 November 2010.

Brazil. "Plano de Trabalho da Comissão para avaliar a Política Nacional de Segurança de Barragens e o Sistema Nacional de Informações sobre Segurança de Barragens", Senate Congress, 1 December 2015.

Brazil. "Preliminary Report of the External Commission on the Dam Breach in the Region of Mariana - MG", Chamber of the Representatives - Congress, CD158408782307, December 2015.

Brazilian Water National Agency. "Encarte Especial sobre a Bacia do Rio Doce Rompimento da Barragem em Mariana/MG", Superintendência de Planejamento de Recursos Hídricos, Brasília, 2016.

Bruno Milanez et al. "Antes fosse mais leve a carga: avaliação dos aspectos econômicos, políticos e sociais do desastre da Samarco/Vale/BHP em Mariana (MG)", Final Report of PoEMAS, Federal University of Juiz de Fora, December 2015..

Bruno Ribeiro et al., "Estudo de 2013 alertava para risco de barragem romper", Estado de São Paulo, 7 November 2015. Available at: 
$<$ http://brasil.estadao.com.br/noticias/geral,estudo-de-2013-alertava-para-risco-debarragem-romper,10000001364>.

Budayeva v. Russia, Applications No. 15339/02, 21166/02, 20058/02, 11673/02 and 15343/02, ECtHR, Judgment of 20 March 2008.

Burkina Faso. Loi No. 002-2001/AN Portant Loi d'Orientation Relative a la Gestion de l'Eau, 8 February 2001.

Cambodia. Law on Water Resources Management of the Kingdom of Cambodia, 29 June 2007.

Case of the Ituango Massacres (Merits) IACtHR, Judgment of July 1, 2006, paras.130 and 131. Case of the Street Children (Villagran-Morales et al. $v$ Guatemala) (Merits) IACtHR, Judgment of November 19, 1999.

Chongwe v. Zambia, Comm. No. 821/1998, UNHRC, Oct. 25, 2000.

Committee on Economic, Social and Cultural Rights, General Comment No. 15: The Right to Water (Arts. 11 and 12 of the Covenant), 29th Session of the Committee on Economic, Social and Cultural Rights, Doc.E/C.12/2002/11, 20 January 2003.

Committee on Economic, Social and Cultural Rights, General Comment 14: The right to the highest attainable standard of health, 22nd Session of the Committee on Economic, Social and Cultural Rights, U.N.Doc.E/C.12/2000/4, 2000.

Convention on the Elimination of All Forms of Discrimination against Women, 1249 UNTS 1, 1 March 1980.

Convention on the Prevention and Punishment of the Crime of Genocide, 78 UNTS 277, 9 December 1948.

Convention on the Rights of Persons with Disabilities, 2515 UNTS 3, New York, 13 December 2006, art.28(2)(a).

Convention on the Rights of the Child, 1577 UNTS 3, New York, 20 November 1989.

Daniel Camargos. "Plano de emergência para barragens da Samarco era ineficaz, acusa Polícia Federal", Estado de Minas, 31 January 2016. Available at: 
$<$ http://www.em.com.br/app/noticia/gerais/2016/01/31/interna_gerais,730015/plano-deemergencia-para-barragens-da-samarco-era-ineficaz-acusa-pf.shtml>.

Deanna Kem et al. "Mining, water and human rights: making the connection", Journal of Cleaner Production, vol.18, 1553-1562, 2010.

Democratic Republic of the Congo. Constitution of the Democratic Republic of the Congo, 18 February 2006.

Departamento de Pesquisas e Estudos Econômicos. "Minério de Ferro", Bradesco Bank, 2016.

Ecuador. Constitution of the Republic of Ecuador, 20 October 2008.

F. Menghistu, "The Satisfaction of Survival Requirements". In Bertrand G. Ramcharan (ed.). The Right to Life in International Law, Leiden: Martinus Nijhoff, 1985.

France. Code de l'environnement, 2000.

Geraldo Wilson Fernandes et al. "Deep into the mud: ecological and socio-economic impacts of the dam breach in Mariana, Brazil", Natureza e Conservação, vol.14, 2016.

Gustavo Werneck. "Plano de emergência para barragens da Samarco era ineficaz, acusa Polícia Federal", Estado de Minas, 31 January 2016. Available at: $<$ http://www.em.com.br/app/noticia/gerais/2015/11/24/interna_gerais,710870/samarcocontratou-plano-de-emergencia-para-desastre-mas-nunca-pos-em.shtml .

Haruf Salmen Espindola, "Vale do Rio Doce: Fronteira, industrialização e colapso socioambiental", Fronteiras: Journal of Social, Technological and Environmental Science, v.4, n.1, 2015, p. 160-206.

Herton Escobar. "Mud tsunami wreaks ecological havoc in Brazil", Science, vol. 350, issue 6265, 2015.

International Covenant on Civil and Political Rights, 16 December 1966, 999 UNTS 171.

International Covenant on Civil and Political Rights, 1966, 999 UNTS 171.

International Covenant on Economic, Social and Cultural Rights, (1966), 993 U.N.T.S.

RRASILIANA- Journal for Brazilian Studies. Vol. 5, n.2 (July 2017). ISSN 2245-4373. 
Itamar Souza Ferreira Krenak et al. Água, leito das vidas Krenak, Uatu Hoom, Cipó Voador, 2009.

João Daniel Lima de Almeida. História do Brasil, Brasília: FUNAG, 2013, p.44-52.

John Scanlon, Angela Cassar \& Noémi Nemes. "Water as an Human Right?", Environmental Law and Policy Paper No. 51, International Union for Conservation of Nature, 2004.

José Teixeira de Oliveira, História do Estado do Espírito Santo, 3rd ed., Vitória, Arquivo Público do Estado do Espírito Santo, Secretaria de Estado da Cultura, 2008.

Kenya. Constitution of Kenya, 28 August 2010.

Lantsov v. Russia, Comm. No. 763/1997, UNHRC, Mar. 26, 2002.

Maldives. Constitution of the Republic of the Maldives, 7 August 2008.

Marcelo Leite and Estevão Bertoni, "'Barragem que se rompeu não voltará a funcionar', diz presidente da Samarco", Folha de São Paulo, 26 December 2015. Available at: $<$ ttp://www1.folha.uol.com.br/cotidiano/2015/12/1723149-barragem-que-se-rompeu-naovoltara-a-funcionar-diz-chefe-da-samarco.shtml>.

Maria Hilda Paraíso. "Os Botocudos e sua Trajetória Histórica”. In: Manuela Carneiro da Cunha (ed.). História dos Índios no Brasil. São Paulo: Fapesp/SMC/CIA das Letras, 1992.

Minas Gerais State Environmental Foundation - FEAM, "Inventory of dams in the State of Minas Gerais", Doc. no. FEAM-DGER-GERIM-RT-03/2015, 2016.

Movimento dos Atingidos por Barragens, "Infográfico da tragédia: Os números da maior tragédia ambiental brasileira", 2016. Available at: <http://tragedianunciada.mabnacional.org.br/2015/12/15/infografico-da-tragedia/>.

Nicaragua. Nicaragua's Constitution of 1987 with Amendments through 2005, 1 January 1987.

Niger. La Constitution de la VIlème République, 18 February 2010.

Office of the United Nations High Commissioner for Human Rights, "Brazilian mine disaster: 'This is not the time for defensive posturing' - UN rights experts", Press Release, Geneva, 25 November $2015 . \quad$ Available at: 
$<$ http://www.ohchr.org/en/NewsEvents/Pages/DisplayNews.aspx?NewsID=16803\&LangI $\mathrm{D}=\mathrm{E}>$

Olintho Pereira da Silva, "A mineração em Minas Gerais: passado, presente e futuro", Geonomos, vol.3, no.1, 1995.

Öneryildiz v. Turkey, Application No. 48939/99, ECtHR, Judgment of 30 November 2004.

Osman v. United Kingdom, Application No. 23452/94, ECtHR, Judgment of 28 October 1998.

Pedro Rocha Franco, "Laudo técnico alertou para instabilidade em área de barragem em Mariana", Estado de Minas, 6 November 2015. Available at: $<$ http://www.em.com.br/app/noticia/gerais/2015/11/06/interna_gerais,705089/laudotecnico-alertou-para-instabilidade-em-area-de-barragem-em-marian.shtml> .

Peter H. Gleick, "The Human Right to Water", Pacific Institute, 2007.

Prístino Institute, "Laudo Técnico em resposta ao Parecer Único № 257/2013: Análise Técnica Referente à Revalidação da Licença Operacional da Barragem de Rejeitos do Fundão - Samarco Mineração S/A", Belo Horizonte, 21 October 2013. Available at: $<$ http://crimideia.com.br/miniver/wp-content/uploads/2015/11/Laudo-barragem-daSamarco-em-2013.pdf>.

SAMARCO. Parecer de Licenciamento Ambiental. Available at: <http://giaia.eco.br/wpcontent/uploads/2015/11/PARECER-UNICO-N\%C2\%BA-262-2013.-PROTOCOLO1782789-2013_Samarco.pdf>.

South Africa. Constitution of the Republic of South Africa, as last amended by Amendment Act No. 3 of 20031996, 10 December 1996.

Sri Lanka. National Policy on Drinking Water, 2007.

Stephen C. McCafrrey. "A Human Right to Water: Domestic and International Implication", Georgetown Environmental Law Review, vol.5, 1992.

The Dublin Statement on Water and Sustainable Development, International Conference on Water and the Environment, Dublin, Ireland, 31 January 1992. 
The human right to water and sanitation, UNGA Resolution 64/292, UNDoc.A/RES/64/292, 3 August 2010.

The human right to water and sanitation, UNGA Resolution 64/292, UNDoc.A/RES/64/292, 3 August 2010.

The right to development, UNGA Resolution 54/175, UNDoc.A/RES/54/175, 15 February 2000.

Tunisia. Constitution de la République Tunisienne, 26 January 2014.

Ukraine. The Law of Ukraine On Ensuring Sanitary and Epidemic Safety of the Population, 7 February 2002.

UN Commission on Human Rights, Human Rights and Extreme Poverty, Human Rights Res. 2005/16.

UN General Assembly. "General Assembly Adopts Resolution Recognizing Access to Clean Water, Sanitation as Human Right, by Recorded Vote of 122 in Favour, None against, 41 Abstentions", Press Conference no. GA/10967, 28 July 2010. Available at: $<$ http://www.un.org/press/en/2010/ga10967.doc.htm>.

UN Human Rights Council. "Report of the Special Rapporteur on the implications for human rights of the environmentally sound management and disposal of hazardous substances and wastes, Başkut Tuncak", UNDoc.A/HRC/30/40, 8 July 2015.

UN International Law Commission. Sixth report on the protection of persons in the event of disasters, Special Rapporteur Eduardo Valencia-Ospina, UNDoc.A/CN.4/662, 3 May 2013.

UN Sub-Commission on Prevention of Discrimination and Protection of Minorities, Revised and updated report on the question of the prevention and punishment of the crime of genocide prepared by Mr. B. Whitake, UNDoc.E/CN.4/Sub.2/1985/6, 2 July 1985.

UNHRC, General Comment No.6: The right to life (art. 6), CCPROR, UNDoc.HRI/GEN/1/Rev.1, 1994.

Uruguay. Constitución de la República Oriental del Uruguay, 15 February 1967.

Velasquez Rodriguez $v$. Honduras (Merits) IACtHR, Judgment of 29 July 1988, Series C, No. 4. 
William A. Schabas. Genocide in International Law: The Crime of Crimes, 2 ed., Cambridge, Cambridge University Press, 2009.

Yoram Dinstein. "Collective Human Rights of Peoples and Minorities", International $\mathcal{E}$ Comparative Law Quarterly, Vol. 25, Issue 1, Jan de 1976, p102-120. 